\title{
Antibacterial Activity of n-Hexane Extract of Ocimum gratissimum leaves
}

\author{
M.M. Ekwenchi, J. Oluigbo, A.Akpuaka \\ Department of Chemistry, Faculty of Natural Sciences University of Jos, Jos, Plateau State, Nigeria.
}

\begin{abstract}
The antibacterial activity of $n$-hexane extract of Ocimum gratissimum leaves was investigated against gram negative bacteria (Salmonella typhi) and gram positive bacteria (Staphylococcus aureus). Agar well diffusion and broth dilution methods were employed. The results revealed that both first and second $n$ hexane extracts (4days and 8 days $n$-hexane extract respectively) inhibited the microorganisms with the second being more active as it inhibited at $30 \mathrm{mg} / \mathrm{ml}, 40 \mathrm{mg} / \mathrm{ml}, 50 \mathrm{mg} / \mathrm{ml}$ and $100 \mathrm{mg} / \mathrm{ml}$ with zone of inhibition ranging from $8.5 \mathrm{~mm}$ to $15.5 \mathrm{~mm}$ in diameter. The first extract showed no inhibition at $30 \mathrm{mg} / \mathrm{ml} \mathrm{and} 40 \mathrm{mg} / \mathrm{ml}$ respectively but showed inhibition at $50 \mathrm{mg} / \mathrm{ml}$ and $100 \mathrm{mg} / \mathrm{ml}$ with zone of inhibition ranging from $9 \mathrm{~mm}$ to $12 \mathrm{~mm}$ in diameter. The Minimum Inhibitory Concentration (MIC) of the second n-hexane extract ranged from $25 \mathrm{mg} / \mathrm{ml}$ to $100 \mathrm{mg} / \mathrm{ml}$ whereas, that for the first was at $100 \mathrm{mg} / \mathrm{ml}$. The result was compared to conventional drug (Gentamicin 20ug/ml) with zone of inhibition at 20mm in diameter. The Gas Chromatography Mass Spectrometry (GC/MS) identified antibacterial compounds which include Hexadecanoicacid, Phytol, Ricinoleicacid, Dehydrodihydrodiisoeugenol and 9-Octadecenamide. Based on the results it can be concluded that Ocimum gratissimum leaves extract possess antibacterial activity and can be applied in development of potent antibacterial drugs.
\end{abstract}

Keywords: Ocimum gratissimum, n-hexane extract, antibacterial activity, Gas Chromatography Mass Spectrometry $(G C / M S)$

\section{Introduction}

Diseases are growing more resistant to synthetic drugs leading to researchers finding better alternatives from plant resulting to the comeback of 'green medicine'. Salmonella typhi a gram negative, rod shaped motile and anaerobic bacteria from genus Salmonella and family Enterobacteriaceae [1], the causal organism of typhoid fever. There has been resistance of this disease to ampicillin, chloramphenicol, trimethoprimsulfamethoxazole and streptomycin [2].Staphylococcus aureus gram positive cocci and anaerobic bacteria, causal organism of skin infections, pneumonia and food poisoning.

Ocimum gratissimum from the family Lamiacea and genus Ocimum is a perennial herb found in tropical and temperate region. It is the species commonly found in Nigeria. It is well known for its nutritional and medical properties. It has long been used in folkloric medicine to treat fever, skin infections and respiratory tract infections [3]. It is antifungal [4], [5], antibacterial [6], [7], antiviral [8], antileshmanial [9], antitrypanosomal [10], antidiabetic [11], anticonvulsant [12], antioxidant [13]. Phytochemical analysis [14] confirmed the presence of alkaloids, tannins, phenolics, saponins, glycoside, and resins. Steroids and terpenoids were also confirmed to be present in the plant [15]. GC/MS of its essential oil (ocimum oil) [16] showed eugenol to be major component, thymol, germacrene, bisabolene and other volatiles as minor component. This present study is aimed at determining the antibacterial activity of Ocimum gratissimum leaves.

\subsection{COLLECTION AND EXTRACTION OF PLANT}

\section{Materials And Method}

Ocimum gratissimum leaves were collected from a vegetable garden along Zaria road in Jos North area of Plateau State in April 2013. It was identified by Mr Agyeno of Botany Department University of Jos, Plateau state Nigeria. The leaves were rinsed with water and shade dried at room temperature then pulverized. $50 \mathrm{~g}$ of the powder was extracted for 4 days with $250 \mathrm{ml}$ research grade $\mathrm{n}$-hexane with occasional stirring (twice a day). The marc was separated from the solvent by decantation and labeled first $n$-hexane extract of Ocimum gratissimum leaves $\left(\mathrm{OGH}_{1} \mathrm{E}\right)$. Another $250 \mathrm{ml}$ of $\mathrm{n}$-hexane was added to the marc and left for another 4 days with occasional stirring then decanted and labeled second n-hexane extract of Ocimum gratissimum leaves $\left(\mathrm{OGH}_{2} \mathrm{E}\right)$. Both extracts (first and second $\mathrm{n}$-hexane) were evaporated to constant weight using a steam bath.

\subsection{ANTIBACTERIAL ASSAY}

The microorganisms which were Salmonella typhi and Staphylococcus aureus were sourced from the Department of Pharmaceutical Science and Technology University of Jos. They were sub cultured in $5 \mathrm{ml}$ sterile nutrient broth then incubated at $37^{\circ} \mathrm{C}$ for $24 \mathrm{hrs} .0 .1 \mathrm{ml}$ of the $24 \mathrm{hr}$ broth culture was aseptically introduced into a 
sterile nutrient agar, $20 \mathrm{ml}$ each was then transferred aseptically into petri dishes .Using a $3 \mathrm{~mm}$ cork borer, holes were bored in each agar plate .The wells were filled with $30 \mathrm{mg} / \mathrm{ml}, 40 \mathrm{mg} / \mathrm{ml}, 50 \mathrm{mg} / \mathrm{ml}$ and $100 \mathrm{mg} / \mathrm{ml}$ of the extract dissolved in n-hexane. The plates were then incubated at $37^{0} \mathrm{C}$ for $24 \mathrm{hrs}$. The zone of inhibition of each well was obtained in millimeters. Gentamicin served as the positive control while n-hexane was used as the negative control.

\subsection{DETERMINATION OF MINIMUM INHIBITORY CONCENTRATION (MIC)}

This was done by the broth dilution method and turbidity of each tube was observed. The controls contained no microorganism only the extract .The lowest concentration showing no turbidity was the MIC.

\subsection{DETERMINATION OF MINIMUM BACTERICIDAL CONCENTRATION (MBC)}

The MBC was further carried out using the tubes that showed no turbidity and then smearing a loopful on a sterile nutrient agar plate, then incubating at $37^{\circ} \mathrm{C}$ for $24 \mathrm{hrs}$ and growth of microorganisms were observed.

The n-hexane extract was chemically analyzed using a QP2010 PLUS SHIMADZU, JAPAN Gas Chromatograph interfaced to a Mass Spectrometer (GC/MS) instrument under the following conditions : AOC$20 \mathrm{i}$ auto injection, fused silica capillary column (RTX-5MS : $30 \mathrm{~m} \times 0.25 \mathrm{~mm}$ I.D . $\mathrm{d}$.f $=0.25 \mu \mathrm{m}$ ) which was programmed as follows : flow rate of carrier gas $(\mathrm{He})$ was $1 \mathrm{ml} / \mathrm{min}$, injection port temperature $200^{\circ} \mathrm{C}$, initial temperature of column being $50^{\circ} \mathrm{C}$ increased and kept constant at $300^{\circ} \mathrm{C}$ for 9 mins with heating rate of $8^{0} \mathrm{C} / \mathrm{min}$. The volume injected was $1 \mu \mathrm{l}$ with split mode. Identification of the extract constituents was made based on retention times and by comparison of mass spectra with the computer search using NIST05 library of mass spectral data.

\section{Result}

The percentage yields of first and second n-hexane extract were 3\% and $2 \%$ respectively. Antibacterial activity showed that $\mathrm{n}$-hexane extract had zones of inhibition between $9-12 \mathrm{~mm}$ for the first extract (Table 1) and $8.5-15.5 \mathrm{~mm}$ for the second extract (Table 4). Minimum Inhibitory Concentration (MIC) and Minimum Bactericidal Concentration (MBC) for the first and second extracts are as shown in Tables 2, 3, 5 and 6. The chromatograms for $\mathrm{OGH}_{1} \mathrm{E}$ and $\mathrm{OGH}_{2} \mathrm{E}$ are shown in figures 1 and $2 \mathrm{a}$ respectively. The mass spectra of compounds responsible for antibacterial activity are presented in figures $2 \mathrm{a}_{1}$ to $2 \mathrm{a}_{5}$.

Table 1: Antibacterial activity of first n-hexane extract of Ocimum gratissimum leaves $\left(\mathrm{OGH}_{1} \mathbf{E}\right)$.

\begin{tabular}{lcccccc}
\hline & Zones of inhibition of $\mathrm{OGH}_{1} \mathrm{E}(\mathrm{mm}) /$ Concentration $(\mathrm{mg} / \mathrm{ml})$ & & \\
\hline Microorganisms & 30 & 40 & 50 & 100 & Gentamicin $(20 \mathrm{ug} / \mathrm{ml})$ \\
Salmonella typhi & - & - & 11 & 12 & 20 & $\mathrm{n}-\mathrm{Hexane}$ \\
Staphylococcus aureus & - & - & 9 & 12 & 20 \\
\hline
\end{tabular}

Staphylococcus aureus

Table 2: Minimum Inhibitory Concentration (MIC) of the first n-hexane extract of Ocimum gratissimum leaves.

\begin{tabular}{lcccrr}
\hline \multicolumn{7}{c}{ MIC / Concentration $(\mathrm{mg} / \mathrm{ml})$} & & & \\
\hline Microorganisms & 6.125 & 12.5 & 25 & 50 & 100 \\
Salmonella typhi & + & + & + & + & + \\
Staphylococcus aureus & + & + & + & + & + \\
\hline
\end{tabular}

$+=$ Turbidity

- $=$ No turbidity

Table 3: Minimum Bactericidal Concentration (MBC) of the first n-hexane extract of Ocimum gratissimum leaves.

\begin{tabular}{|c|c|c|c|c|c|}
\hline \multicolumn{6}{|c|}{ MBC / Concentration (mg/ml) } \\
\hline Microorganisms & 6.125 & 12.5 & 25 & 50 & 100 \\
\hline Salmonella typhi & N.T & N.T & N.T & N.T & + \\
\hline Staphylococcus aureus & N.T & + & + & + & + \\
\hline
\end{tabular}

$+\quad=$ Growth

N.T $=$ Not tested

Table 4: Antibacterial activity of second n-hexane extract of $\left.\mathrm{Ocimum}_{\text {gratissimum leaves }(\mathrm{OGH}} \mathrm{E}\right)$.

\begin{tabular}{lcccccc}
\hline & Zones of inhibition of $\mathrm{OGH}_{2} \mathrm{E}(\mathrm{mm})$ & / Concentration $(\mathrm{mg} / \mathrm{ml})$ & & \\
\hline Microorganisms & 30 & 40 & 50 & 100 & Gentamicin $(20 \mathrm{ug} / \mathrm{ml})$ & $\mathrm{n}-\mathrm{Hexane}$ \\
Salmonella typhi & 9 & 10.5 & 12 & 15.5 & 20 & - \\
Staphylococcus aureus & 8.5 & 10 & 11 & 12 & 20 & - \\
\hline
\end{tabular}


$-\quad=$ No inhibition

Table 5: Minimum Inhibitory Concentration (MIC) of second n-hexane extract of Ocimum gratissimum leaves.

\begin{tabular}{lccccc}
\hline \multicolumn{7}{c}{ MIC / Concentration (mg/ml) } & & & \\
\hline Microorganisms & 6.125 & 12.5 & 25 & 50 & 100 \\
Salmonella typhi & + & + & + & - & - \\
Staphylococcus aureus & + & + & - & - \\
\hline
\end{tabular}

$+=$ Turbidity

$-\quad=$ No turbidity

Table 6: Minimum Bactericidal Concentration (MBC) of second n-hexane extract of Ocimum gratissimum leaves.

\begin{tabular}{lccccc}
\hline \multicolumn{7}{c}{ MBC/ Concentration $(\mathrm{mg} / \mathrm{ml})$} & & & \\
\hline Microorganisms & 6.125 & 12.5 & 25 & 50 & 100 \\
\cline { 2 - 6 } Salmonella typhi & N.T & N.T & N.T & - & - \\
Staphylococcus aureus & N.T & N.T & + & & - \\
\hline$-\quad=$ No growth & & & & \\
$+\quad=$ Growth & & & &
\end{tabular}

N.T $=$ Not tested

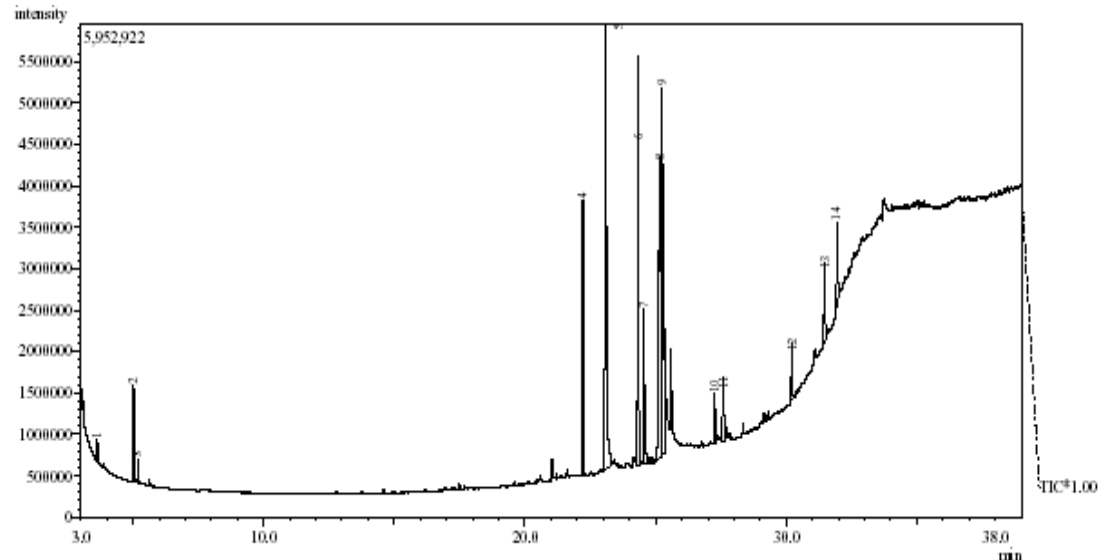

Figure 1: Chromatogram of $\mathrm{OGH}_{1} \mathrm{E}$

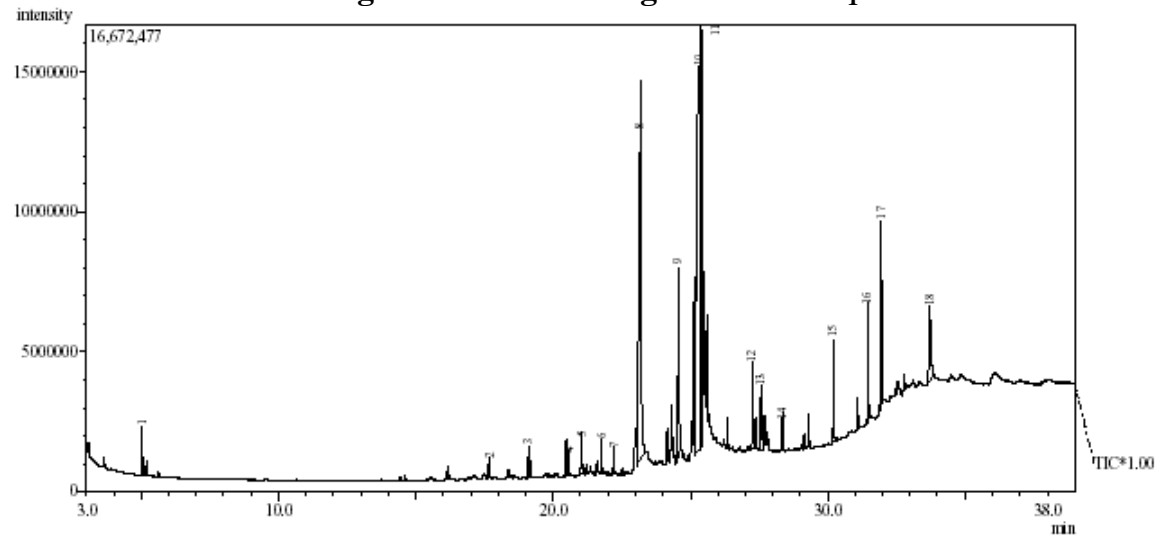

Figure 2a: Chromatogram of $\mathrm{OGH}_{2} \mathrm{E}$

R.T 23.108min Hexadecanoic acid

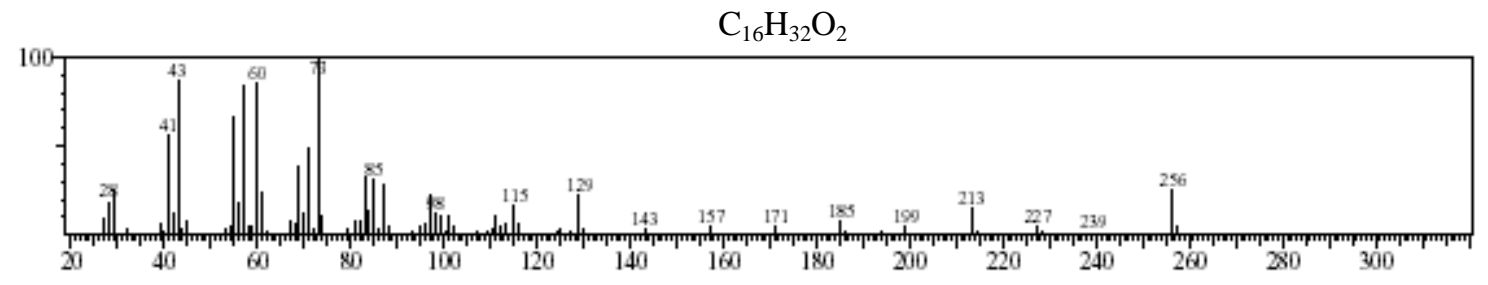



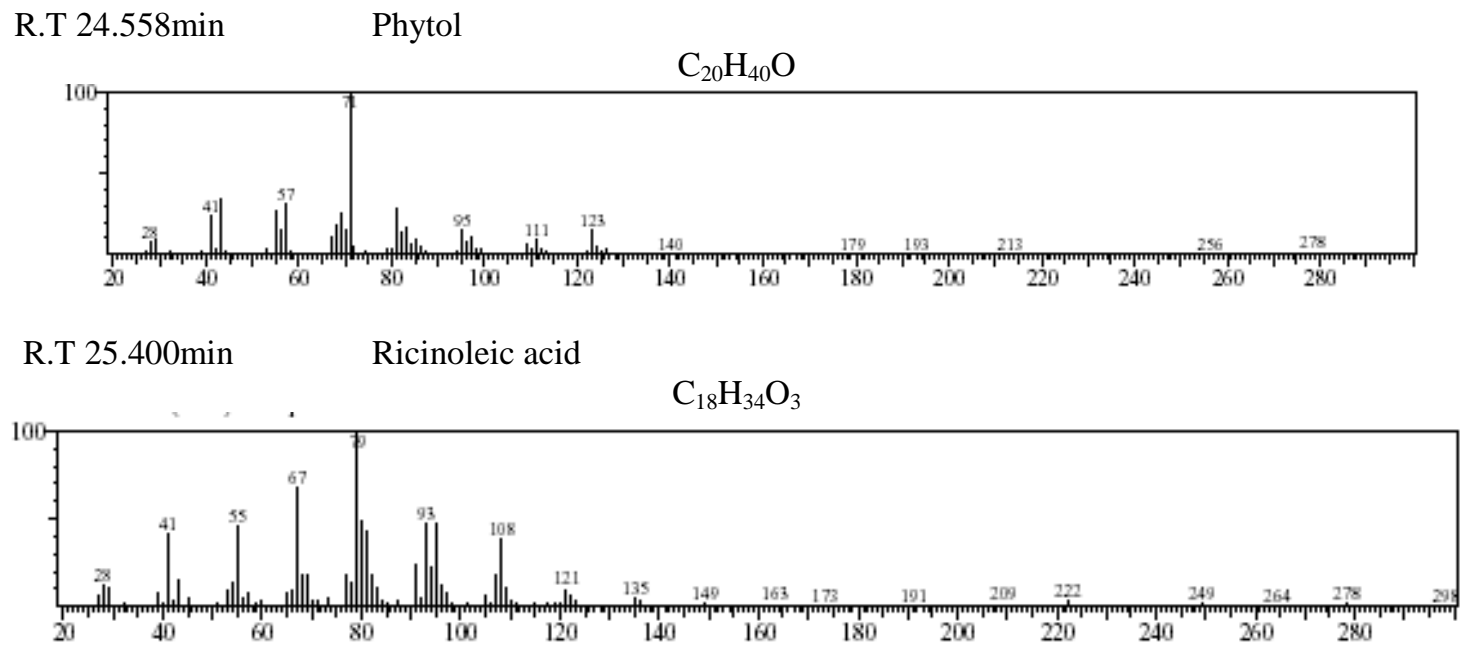

R.T 27.258min Dehydrodihydrodiisoeugenol

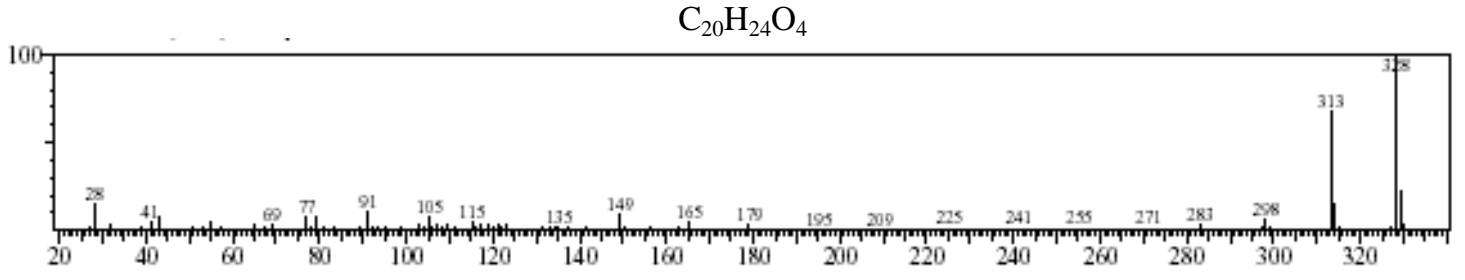

R.T 27.575min 9-Octadecenamide

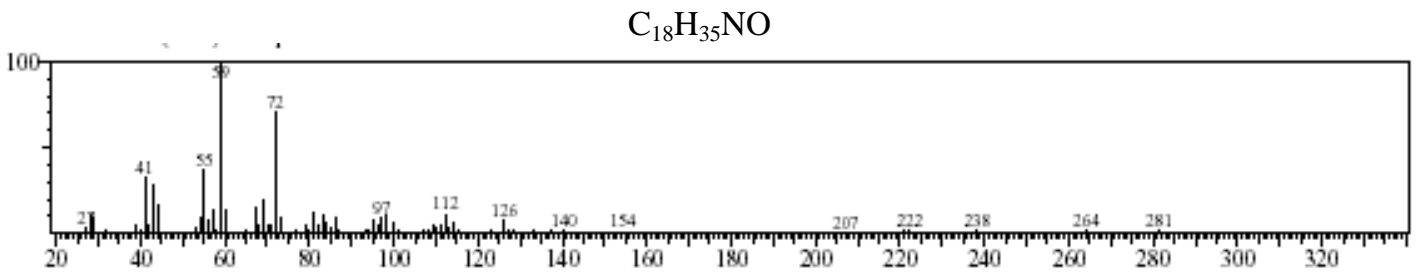

Figures 2a $a_{1}$ to 2a $a_{5}$ : Mass spectra of compounds responsible for antibacterial activity according to their retention times (R.T).

\section{Discussion}

The present study showed that the n-hexane extract of Ocimum gratissimum leaves inhibited the growth of both microorganisms. It can also be seen that the extract was both bacterostatic and bactericidal.

From chromatogram of $\mathrm{OGH}_{1} \mathrm{E}$, Peak 5 which is the highest is hexadecanoic acid with R.T 23.108min.Peak 7 is phytol with R.T $24.550 \mathrm{~min}$. Dehydrodihydrodiisoeugenol is peak 10 with R.T $27.267 \mathrm{~min}$. 9-Octadecenamide is peak 11 with R.T 27.600min. From chromatogram of $\mathrm{OGH}_{2} \mathrm{E}$, peak 8 is hexadecanoic acid also in high proportion with R.T $23.175 \mathrm{~min}$. Peak 9 is phytol higher than that in $\mathrm{OGH}_{1} \mathrm{E}$ with R.T $24.558 \mathrm{~min}$. Peak 11 being the highest peak is ricinoleic acid with R.T $25.400 \mathrm{~min}$. Peak 12 is dehydrodihydrodiisoeugenol higher than that in $\mathrm{OGH}_{1} \mathrm{E}$ with R.T 27.258. 9-octadecenamide is peak 13 with R.T 27.575min.From the chromatograms it can be inferred that the retention times of the compounds are similar and increase in dehydrodihydrodiisoeugenol, phytol and especially the presence of ricinoleic acid in $\mathrm{OGH}_{2} \mathrm{E}$ lead to increase in antibacterial activity and inhibition of bacterial strains at low concentrations. Hexadecanoic acid has been shown to be a potent antibacterial compound [17], [18]. Phytol has been shown to possess activity against Salmonella typhi and resistant gonorrhea [19]. Eugenol and isoeugenol has also been observed to possess antibacterial activity [20], so dehydrodihydrodiisoeugenol being a phenolic compound could exhibit certain antibacterial activity. Ricinoleic acid being the major component of castor oil also possesses antibacterial and antifungal properties [21]. 


\section{Conclusion}

The data analysis of this work has shown Ocimum gratissimum to be effective against gram positive and gram negative strains of bacteria making it a broad spectrum antibacterial drug and provides the possibility of treating various bacterial infections by applying it in production of pharmaceuticals.

\section{Acknowledgement}

The authors are grateful to Department of Chemistry and Pharmaceutical sciences/technology University of Jos for their laboratory facilities.

\section{References}

[1]. OcheiKolhatkar, Medical laboratory science theory and practice, six edition 2007

[2]. Typhoid fever-Wikipedia, the free encyclopedia. http://en.m.wikipedia.org/wiki/Typhoid-fever.

[3]. Adebolu T.T, Oladimeji S.A. Antimicrobial Activity of Leaf Extract of Ocimum gratissimum on Selected Diarrhea causing Bacteria in South West Nigeria. African Journal of Biotechnology, 4(7), 2005, 682- 684.

[4]. Dubey N.K, Tiwari T.N, Mandin D, Andriamboavonjy H, Chaumont J.P. Antifungal Properties of Ocimum gratissimum Essential oil (ethyl cinnamatechemotype). Fitoterapia, 71, 2000, 567-569.

[5]. Terezinha de Jesus Faria, Rafael Sottero Ferreira, LidianeYassumoto, Jose' Robert, Pinto de Souza, Noemia Kazue Ishikawa and Aneli de Melo Barbosa. Antifungal Activity of Essential oil Isolated from Ocimum gratissimum L. (eugenolchemotype) against Phytopathogenic fungi. Brazilian Archives of Biology and Technology, 49(6), 2006, 867-871.

[6]. Junaid S.A, Olabode A.O, Onwuliri F.C, Okwori A.E and Agina S.E. The Antimicrobial Properties of Ocimum gratissimum Extract on some Selected Bacterial Gastrointestinal Isolates. African Journal of Biotechnology, 5(22), 2006, 2315-2321.

[7]. Matasyoh L.G, J.C Matasyoh, F.N Wachira, M.G Kingua, A.W ThairuMuigai, T.K Mukiama. Antimicrobial Activity of Essential oils of Ocimum gratissimum L. from Different Populations of Kenya. Afr.J.Trad.CAM, 5(2), 2008, 187-193.

[8]. Ayissi N.K and Nyadedzor C. Comparative in-vitro effects of AZT and Extracts of Ocimumgratissimum, Ficuspolita, Clausenaanisata, Alchorneacordifolia, and Elaephorbiadrupifera against HIV-1 and HIV-2 infections. Antiviral Res, 58, 2003, 2533.

[9]. Ueda-Nakamura T, R.R Mendonca- Filho, J.A Moryo do-diaz, P.K Maza and B.P.D Fiho. Antileishmanial Activity of eugenol-rich Essential oil from Ocimum gratissimum. Parasitol.Int, 55, 2006, 99-105.

[10]. Adamu M, Nwonsu C.O, Agbede R.I.S. Antitrypanosomal Effects of Aqueous Extract of Ocimumgratissimum (Lamiaceae) Leaf in rats infected with Trypanosome bruceibrucei. Afr.J.Trad CAM, 6(3), 2009, 262-267.

[11]. Aguiyi J.C, E.L Obi, S.S Gand and A.C Igweh. Hpoglycemic Activity of Ocimum gratissimum in rats. Fitoterapia, 71, 2000, 444446.

[12]. Freire C.M.M, Marques M.O.M and Costa M. Effects of Seasonal Variation on the Central Nervous System Activity of Ocimum gratissimum L. Essential oil. J.Ethnopharmacol, 105, 2006, 161-166.

[13]. Aprioku J.S, Obianime A.W. Antioxidant Activity of Aqueous Crude Extract of OcimumgratissimumLinn.Leaf on Basal and Cadmium-induced Serum Levels of Phosphatases in Male guinea-pigs. J.Appl.Sci.Environ.Manage, 12(4), 2008, 33 -39.

[14]. Koche D.K, Kokate P.S, Suradkar S.S and Bhadange D.G. Preliminary Phytochemical and Antibacterial Activity of Ethanolic Extract of Ocimum gratissimum L. Bioscience Discovery , 3(1), 2012, 20-24.

[15]. Ladipo M.K, Doherty V.F and Kanife U.C. Phytochemical screening and Antibacterial Investigation of the Extract of Ocimum gratissimum (scent leaf) on Selected Enterobacteriaceae. PAT, 6(2), 2010, 75-84.

[16]. Janine de Aquino Lemos, XistoSenaPassos, Orionaida de Fatima LisboaFernande, Jose'Realino de Paula, Pedro Henrique Ferri, Lucia KiokoHasimoto de Souza, Aline de Aquino Lemos, Maria de Rosario, Rodriques Silva. Antifungal Activity from Ocimum gratissimum L. toward Cryptococcus neoformans. Mem. Inst. Oswaldo Cruz, 100(1), 2005, 55-58.

[17]. M.C Graw, L.J Jager, A.K Vanstaden J. Isolation of Antibacterial fatty acids from Schotiabrachypetala. Fitoterapia, 73, 2002, 431433.

[18]. Seidel V, Taylor P.W. In-vitro Activity of Extract and Constituents of Pelegonium against rapidly growing Mycobacteria. Int.J.Antimicrob.Agent, 23, 2004, 613-619.

[19]. Akpuaka A, Ekwenchi M.M, Dashak D.A, Dildar A. Biological Activities of Characterized Isolates of n-Hexane Extract of AzadirachtaindicaA.Juss (Neem) Leaves. Nature and Science, 11(5), 2013, 141-147.

[20]. Matasyoh L.G, Josphat C.M, Francis N.W, Miriam G.K, Anne W.T.M, Titus K.M. Chemical Composition and Antimicrobial Activity of Essential oil of Ocimum gratissimum L. growing in Eastern Kenya. Afr.J.Biotech, 6, 2007, 760-5.

[21]. Medical uses of castor oil. http://sobelarry.hubpages.com/hub/Medical uses of castor-oil. 